Article

\title{
Indicators for the Smart Development of Villages and Neighbourhoods in Baltic Sea Coastal Areas
}

\author{
Maris Kalinka ${ }^{\circledR}$, Sanda Geipele *, Edgars Pudzis $\odot$, Andrejs Lazdins, Una Krutova and \\ Jurijs Holms \\ Riga Technical University, Kalku iela 1, Centra rajons, LV-1658 Rīga, Letonia; maris.kalinka@rtu.lv (M.K.); \\ edgars.pudzis@rtu.lv (E.P.); lazdins.andrejs@gmail.com (A.L.); una.krutova@rtu.lv (U.K.); \\ jurijs.holms@rtu.lv (J.H.) \\ * Correspondence: sanda.geipele@rtu.lv; Tel.: +372-29-449-881
}

Received: 16 April 2020; Accepted: 23 June 2020; Published: 30 June 2020

check for updates

\begin{abstract}
A formal village/neighbourhood planning process is typically focused on three planning levels (national, regional and local) and is usually linked with administrative units of the territory (state, region or municipality). The local planning level (village or neighbourhood) "pocket plan" is a development challenge for spatial planners. The small coastal village Tuja in Latvia was taken as a pilot territory for "pocket planning" due to the unique location; biodiversity and ecosystems; significant natural, cultural, economic and social values; specific interests; and the needs of the involved local society. All these factors create a dynamic flow of data and information. Geographic information systems (GIS) are widely used as planning support systems. GISs for pocket plans must accommodate the special needs of communities in villages and neighbourhoods. Ensuring the availability of information in dynamic real time is an opportunity to build both community integration in specific environments and to understand the future plans of the territory. Access to a WEB-GIS (internet GIS) provides possibilities for every person with a mobile phone to use and update information. Static and statistical information is generally used for spatial planning. For pocket plans, the data and information flow has to be dynamic and has to interact with non-professional users. The special wishes and needs of every member of a community must be accommodated by a pocket plan for the well-being of the people and the sustainability of the surrounding territory. Small territory planning involves a very narrow circle of individuals or communities that identify spatial development needs for the future, which includes the socio-economic, cultural, historical, environmental and climate change scenarios. In order to assess the development opportunities and needs of such areas, the detection, accumulation and monitoring of reliable data is necessary. Methodically derived data (facts) provide objectivity and transparency. Currently, as information between the present and the past is able to circulate very fast, analysis of the current situation to forecast the future and show different constructed realities (scenarios) using a GIS is necessary. Therefore, to explore and determine a local needs-based and smart spatial planning approach, we must identify indicators that can be used for the short-term and long-term analysis of specific territories in coastal areas.
\end{abstract}

Keywords: territory planning; village development; community development; coastal areas; indicators of village/neighbourhood planning; using GIS; GIS layers

\section{Introduction}

\subsection{General Information about this Research}

The objective of the present research was to explore the local territory planning at the Baltic Sea Region in the context of using a geographic information system (GIS) as well as to highlight the 
topicality for the smart and sustainable development of a local needs-based planning approach in coastal areas. The authors emphasize that the local territory described in this research represents a demarcated territory, such as a village or a neighbourhood of a coastal city or town, and includes the community that lives in this territory. The object of the research are villages and neighbourhoods in the Baltic Sea coastal areas, which are considered as territorial communities. MacQueen and other scientists found five core elements of territorial community: (1) Locus, a sense of place, referred to a geographic entity ranging from a neighbourhood to a city, or a particular milieu around which people gather (such as a church or recreation centre). (2) Sharing, common interests and perspectives, referring to common interests and values that can cross geographic boundaries. (3) Joint action, a sense of coherence and identity, including informal common activities, such as sharing tasks and helping neighbours, but these were not necessarily intentionally designed to create community cohesion. (4) Social ties, which involved relationships that created an ongoing sense of cohesion. (5) Diversity, referring not primarily to ethnic groupings, but to the social complexity within communities in which a multiplicity of communities co-exist. [1] Community status derives from the ability to self-organize for concrete purposes in coastal areas.

The present research prioritizes the data that should be collected and monitored to ensure trustworthy, long-term, and smart developments for specific coastal area territories. The in-depth investigation of local needs-based planning approaches will be provided in further research of the indicator analysis tool for new, informed, and objective decisions and vivid solutions in village and neighbourhood territory planning.

To approach the objective of the present research, we developed two indicator groups influencing the smart development of coastal villages or neighbourhoods.

\subsection{Village or Neighbourhood}

Village as a term is very widespread in the description of settlements. A small area may not always be considered as a village but may also be considered as a suburban area or territorial community. As cities and towns evolve, suburban areas are formed and the territories of cities/towns are increasingly divided into informal neighbourhood areas; therefore, diverse types of spatial planning units are created. Outside the urban and sub-urban areas, villages are dispersed-that is, at a great distance from each other or linearly behind each other, for example, coastal villages. Villages as a populated area are of a very dynamic size - they can be transformed into a city/town or may cease to exist as the population increases or decreases [2].

The status of village shall be granted and revoked by the municipality council, based on the local government territorial planning, in which the village border is defined and the need for developing a village is justified [2,3]. Communities and neighbourhoods are informal settlements and are based on the feelings and links of the inhabitants and the physical borders. In the present research, only villages and neighbourhoods with communities were studied.

Community life in local territories depends on the communication and links between the local inhabitants. Typically, a territorial community is a group of people who have similar interests and goals that are territorially limited. Communities that are living in a defined territory must find smart and sustainable ways to develop their neighbourhood. Social, cultural, and economic interest groups are one of the intersections for an active, smart, and sustainable community in a territory.

\subsection{Specific Features of Coastal Areas}

Coastal areas around the Baltic Sea have traditional fishing and cultural communities, such as the Viking culture, and different small ethnographical groups, like the Suite, Kurland, and Gauja cultures in the Baltic region. An integrated approach is needed to provide a strategic, integrated, and forward-looking framework to help achieve both sustainable development and nature conservation [4]. Territories in the coastal areas that are rich with natural, cultural, economic, and social values usually have a diverse range of stakeholders with specific interests and needs. These include local inhabitants 
who live in the territory all year around, seasonal migrants, local municipalities, and representatives of local businesses based on the available sea resources.

Local community life in the coastal areas is strongly dependent on the seasonal migration of the inhabitants, tourism, the existing biodiversity and ecosystem, climate changes, recreation, work opportunities, and natural sea and water resources. The existing biodiversity, ecosystem and climate changes are crucial factors that will affect the future. We highlight the importance and balance among nature, humans and economic growth. Only such a balanced approach can provide a sustainable and smart society in the coastal areas, and the support of technology, including GISs, can help achieve this.

\subsection{Theoretical Aspects of Local Territories Planning}

When investigating coastal territories as rural territories, it is important to consider the rural development policies in the European Union and Baltic Sea region countries. Rural development policies have been based on different theoretical models. A neo-endogenous model is currently in use. This model envisages a greater role and involvement of the local communities in the planning and development processes, while respecting the regional needs and conditions [1-10]. The problems of rural communities in the context of rural development have been directly or indirectly addressed in many studies that characterized the general situation in rural areas of the Baltic Sea region and analysed the public participation in decision-making [5-7]. Europe is experiencing a paradigm shift from the countryside as a place solely linked to agricultural production to a space that offers other services, experiences and goods not only for the rural population but also for citizens and tourists [8]. Increasingly, researchers are emphasizing the use of people-centred as well as area-based approaches to rural and regional development, respecting the local specifics and conditions [9].

Various indicators have long been used in planning, but this does not preclude the development and diversification of the methodology for calculating indicators. An indicator should reflect the phenomenon in the process by tracking its evolution over a sufficiently long period, which also allows the trend to be assessed $[10,11]$. There are numerous definitions of indicators. Broadly speaking, an indicator can be a sign, symptom, signal, tip, clue, grade, rank, object, organism, or warning of some sort, including many things in everyday life. In other words, an indicator is simply "an operational representation of an attribute (quality, characteristic or property) of a system" [12]. Often, four basic dimensions are defined: social; environmental; economic; and institutional. It should be considered that the indicator can carry a certain social burden, promoting public participation in the decision-making process [13].

To ensure sustainable development, a simplified Banfields' [14] rational model can be used in an infinite loop. The loop steps include: (1) data collection, (2) analysis, (3) forecasting the future (planning), establishing goals (planning) and the design of alternatives (planning), (4) assessment, indicator screening and comparing with goals and (5) reactions to the land development trends. If necessary, alternative development plans may be used as the input for step (1) [15]. Reactions to the land development trends can be implemented through 'Stakeholder Dialog' [16].

To more precisely look at the European Union experience in coastal area planning, the authors of this research analysed the Mediterranean Multidimensional Fuzzy Index, which was created by scientists in other parts of the European Union. This index is the basis for methodological research on multidimensional indices, particularly in the areas of sustainability, quality of life and poverty. Fuzzy set theory was shown to be a powerful tool to describe the multidimensionality and complexity of social phenomena, replacing the classical crisp approach, which generally tends to overestimate or underestimate social dynamics. Indicators are used to assess the potential of a site.

A research study by ESPON [17] found that the three key issues for territorial development were: (1) the need to better understand patterns of differentiation between different kinds of rural areas, (2) the nature of the different opportunities for development that each of them faces and (3) the way in which such opportunities depend upon and may be strengthened by interactions between rural and urban areas. For the comparison of experiences, the authors of this research studied experiences 
in local territories by the coast of the Baltic Sea, and indicator groups developed by University of Latvia researchers were used. The sustainable coastal development governance indicator system was developed for the Saulkrasti municipality and accepted by the Saulkrasti local authority as a part of supervision for their municipal long-term strategy and mid-term programs. The system contains 65 indicators, including 19 environmental indicators, divided in seven thematic groups; 20 economic indicators, divided in six thematic groups; 15 social indicators, divided in five thematic groups; 8 governance indicators, divided in three thematic groups; and 3 integral indicators.

The majority of the indicators are integrated at least for two dimensions of sustainability $[10,18]$. In order to understand the trends, continuous data collection and calculations of the indicators should be conducted. A systemic monitoring must cover multiple scales of analysis, be able to link changes in the economy to impacts on the environment and provide sufficient detail to answer policy-relevant questions regarding specific aspects of the bioeconomy in an overarching framework. This has two implications: (1) modelling is a key aspect of a systemic bioeconomy monitoring framework, accompanied by further approaches, such as economy-wide resource accounting and life-cycle analysis and (2) sustainability indicators and targets are essential to evaluate whether the bioeconomy transition is contributing to sustainable development $[19,20]$. A literature review is not only an end in itself but also represents the need to create an analytical tool to achieve the best results.

\section{The case study, materials and methods}

\subsection{Case study}

The study area is Tuja, which is a coastal village in Latvia. This village is located on the coast of the Gulf of Riga (see Figure 1), $33 \mathrm{~km}$ from the government centre Salacgriva district and $75 \mathrm{~km}$ from the capital city of Latvia, Riga. On average, 276 people live in Tūja. In the summer, tourists visit and stay in camping sites. In the territory of Tuja, the territory of detached houses occupies $44 \%$, recreation area occupies $11 \%$, garden plots occupy $2 \%$ and mixed business area occupies $5 \%$ (in approximate distribution). A library is available in Tuja village. In Tuja, there are partly centralized sewer and water supply networks. Tuja is the most popular seaside resort in Vidzeme (the northwest region of Latvia). There are also old fishing traditions. Public services are available to the public. Therefore, the experts chose the Tuja local community as the pilot area.

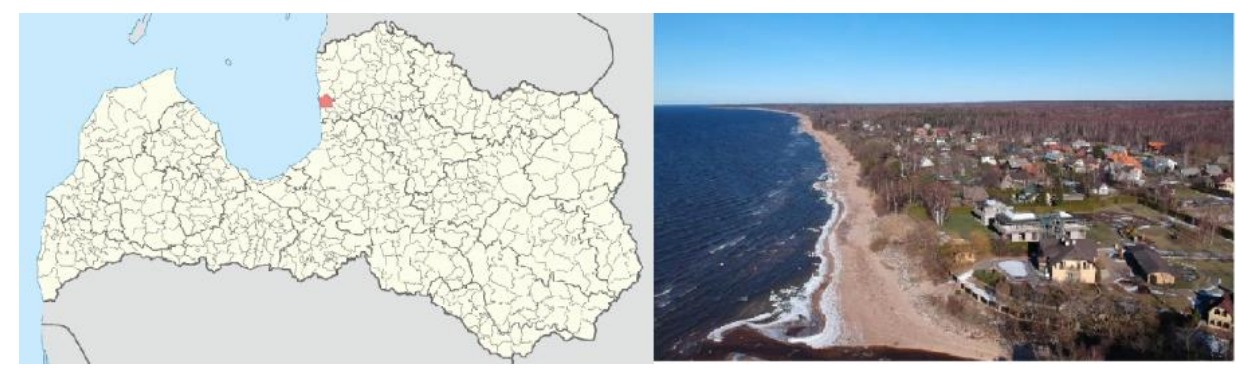

Figure 1. Tuja village location (map developed by the authors).

\subsection{Tool for Data Acquisition and Analysis}

In this research, the systematization of information is one of the prerequisites, as the choice of the key performance indicators depends, to a large extent, on the ability to identify specific sources and process the information flow. This ensures that the information can be used to draw conclusions and decisions. We identify critical elements in the process of selecting key performance indicators: (1) the choice of indicators, (2) the intelligibility and compliance of indicators and (3) the feasibility and credibility of the indicator check process [12].

The GIS plays an important role in the planning process. A customized GIS can be used as a local needs-based planning tool with positive impacts on the economic development, smart growth, quality of life, biodiversity, and ecosystems. 
Powerful indicator assessment tools for sustainable land planning and online decision making built using GIS technologies and new complex approaches based on spatial data infrastructure (SDI) should become available soon [15].

This research highlights how to collect and analyse data for demarked territories and their communities. This is performed in line with the territory development from the perspectives of social-economical relationships and the use of local resources, and demonstrates the use of a GIS. A GIS can be used as a tool to collect, analyse and visualize the geospatial and analytical data to support a transparent and inclusive planning process in a local territory. The main possibilities to use a GIS for planning support include data visualization without geographic coordinates, traditional 2D maps, 3D maps, alternative scenarios and the analysis of multi-attribute tables. The results of this computing can be shown as WEB-GIS layers, thematical maps, dashboards and cartographical maps. WEB-GIS layers are commonly known and users without specific knowledge can combine and analyse layers and obtain useful information for decision making. Dashboards provide the possibility to combine analytical data from analytical databases and display this information on the web, linked with feature layers. Figure 2 shows a dashboard example for the collection of analytical information from government databases and statistical databases regarding the age of village inhabitants. This principle can also be used for dynamical data collection and analysis.

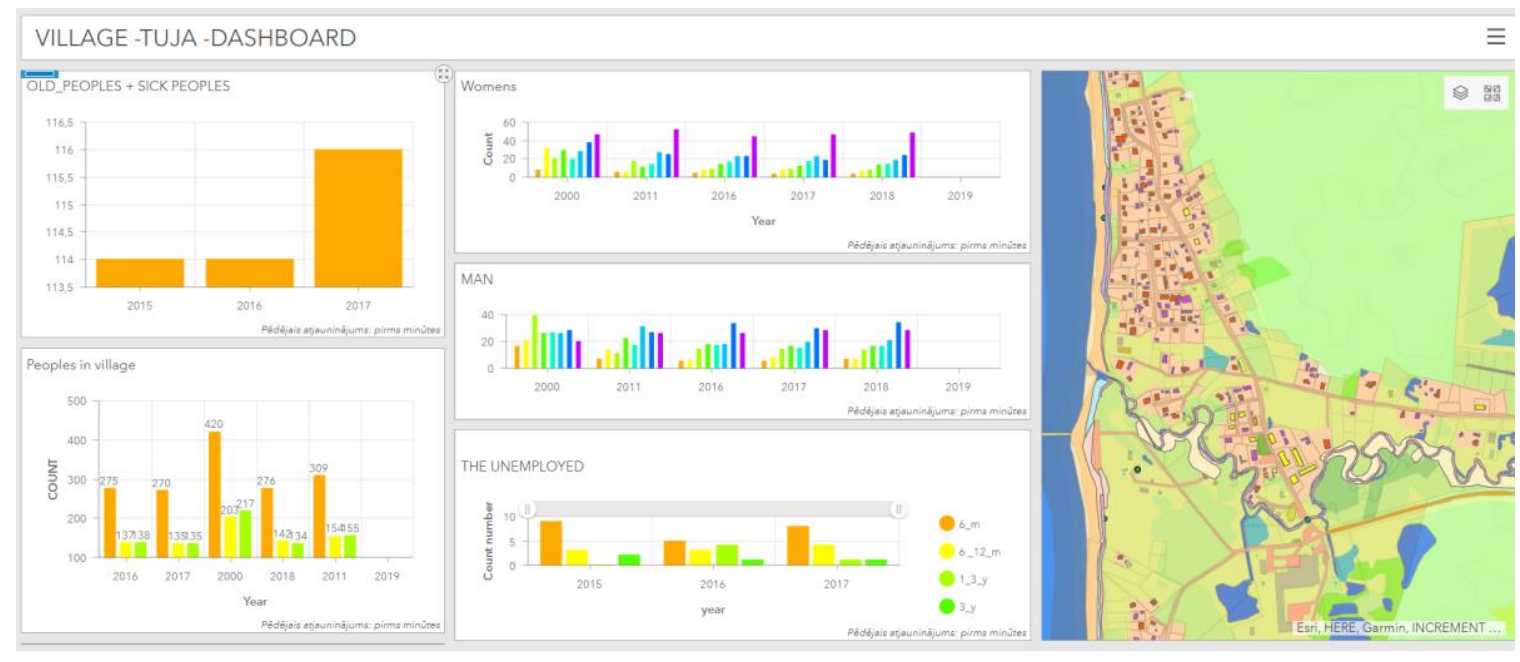

Figure 2. Tuja village dashboard (developed by the authors).

Thematical maps show spatial information created from analytical data and geospatial data. The GIS analysis function allows the combination of feature layers with analytical data. The results of this data combination are new feature layers with new attribute information. Figure 3 shows the building of a thematical map in the WEB-GIS combining the analytical and geospatial information from state and local governments and showing the heights of the houses.

Cartographical maps (base maps) collect different feature layers and can be shown as separate maps with combinations of feature layers by type and visualized using colours and symbology. The base map can be published on a website or printed out and used as a "normal" map. Figure 4 shows a village base map. 


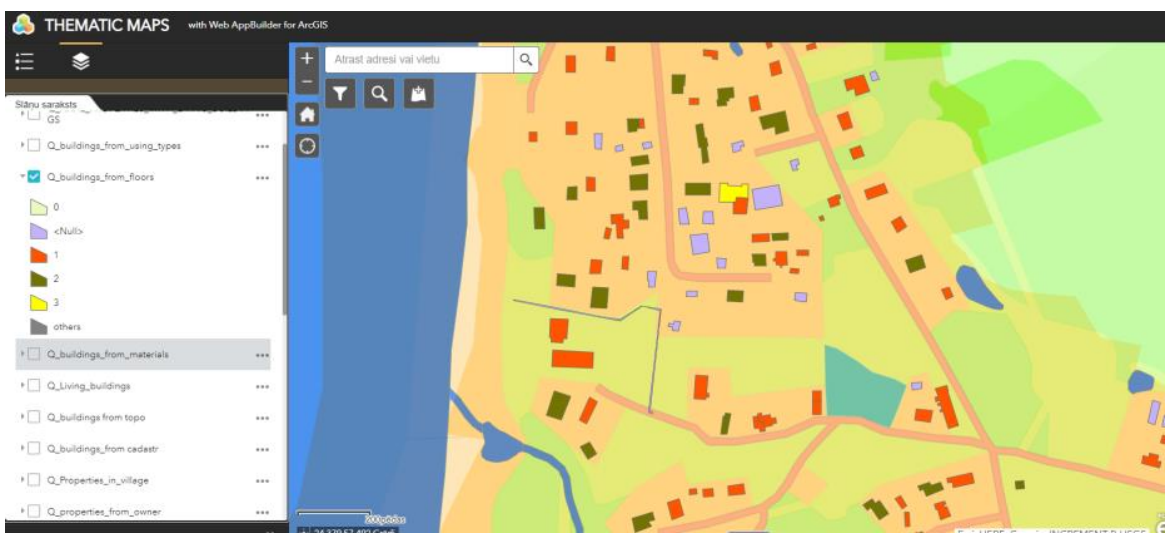

Figure 3. Village thematical map (developed by the authors).

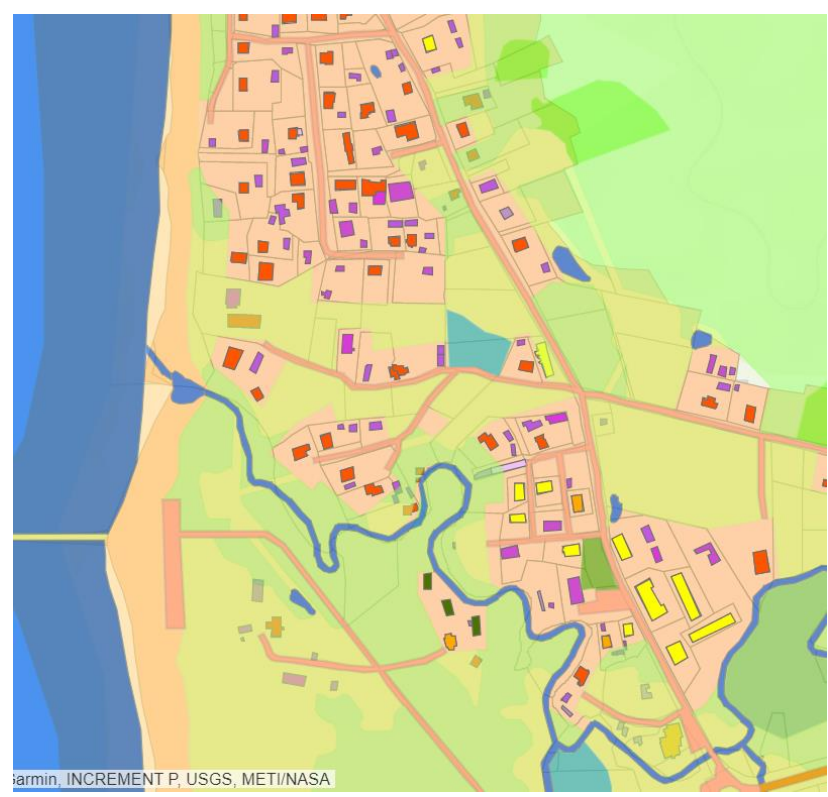

Figure 4. Village base map (developed by the authors).

A literature review, observational data collection, discourse analysis, induction, deduction, synthesis and logical access methods were used in this study. For the identification of the indicators influencing the village and neighbourhood planning in the coastal areas, we used the expert interview method. The selection of experts was based on groups with a direct impact on community life: municipality planning specialists, representatives of the village community, scientists and representatives of the ministry responsible for regional policy.

Social communication methods were used to identify the findings and the need to use them, including seminars, individual discussions and discussions on the meaning and necessity of special tools.

We identified the factors of the systematic strategic process diagram using the mind mapping technique, to help in organizing categories and ideas. Mind maps are used around a central problem to express ideas, created through content analysis, into a visual diagram [21]. They provide imagery and insights by capturing all concepts related to a concern and focusing on the relationships between concepts [22,23]. Conceptual maps stimulate the creation of ideas, rapid results, visual graphical representations and the relationships of the generated ideas [21].

Computer assisted overlay techniques, especially the spatial overlay techniques of geographic information systems (GISs) [24], are very effective for processes involving vector overlap due to their 
advantages in terms of time, cost and labour consumption. A GIS was used in this study to overlap various factor maps and to obtain suitable final maps faster and more efficiently.

\section{Results and Discussion}

\subsection{Discussion: Determining Local Territory Indicators and Using a GIS}

One of the biggest challenges for data model creation is in choosing the appropriate indicators for analysing local territories. There are two principle ways to solve this "indicators" issue. One method to analyse an area is to use different types of indicators that describe the area in terms of the function, structure and location [25]. Using these three large groups would require extensive analysis, including historical, financial, social, ecological and climate data [26]. By covering the indicators of the territory, it is possible for the local community, in cooperation with the municipality, to develop a long-term strategy for the development of the village or neighbourhood territory. One of the important indicators is sociability. The World Health Organization, along with the Office of Disease Prevention and Health Promotion's Healthy People 2020 initiative, identified social support and good social relations as key determinants of health and well-being. The Project for Public spaces showed how to work with different places $[27,28]$. To deal with this challenge, the most important indicators group for the local community are sociability; uses and activities; comfort and image; and access and linkages, which form the subgroups developed by the authors (see Figure 5).

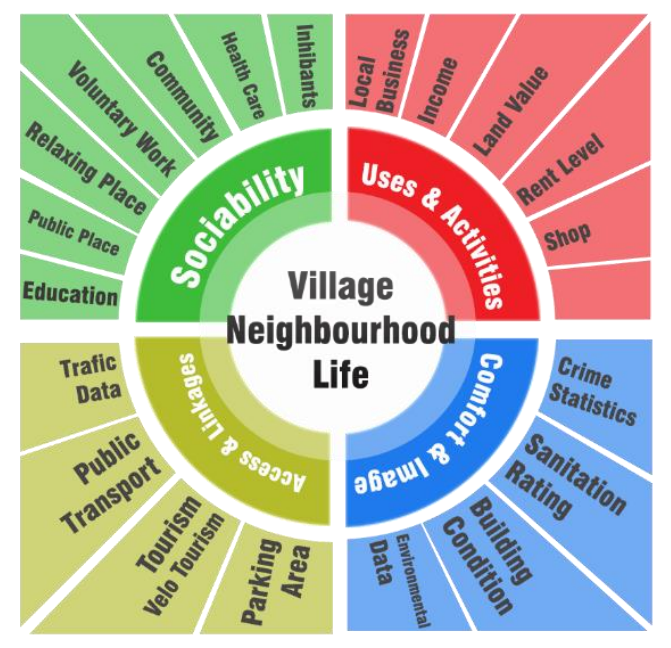

Figure 5. Indicator groups that influence village or neighbourhood planning (developed by the authors).

Another method to analyse local territories is to pay special attention to analysing the historical development of the local territory, to collect its traditions and find a sustainable way for the future to integrate the traditions and culture with developing the territory. This characteristic of local territory may require a unique approach and a focus on different indicators that play roles for the image and attractiveness of the local territory [29]. Regarding the conducted expert interviews, we developed six indicator groups (Table 1):

- economic factors;

- social factors;

- environmental;

- cultural-historical;

- government basket service;

- $\quad$ specific sea resources (in the water and inland). 
Table 1. Indicators influencing village or neighbourhood planning (developed by the authors).

Indicators of the Local Territory

I. Economic factors in the local territory

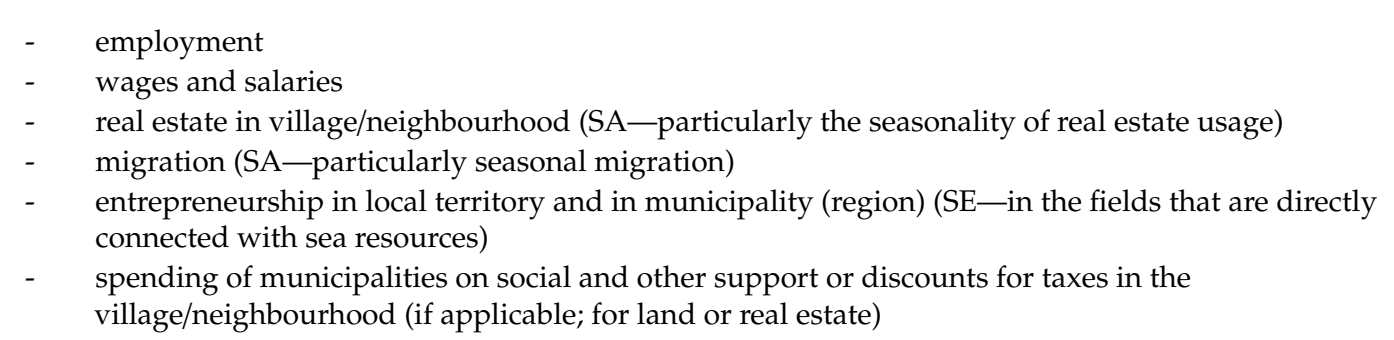

II. Social factors in local territory

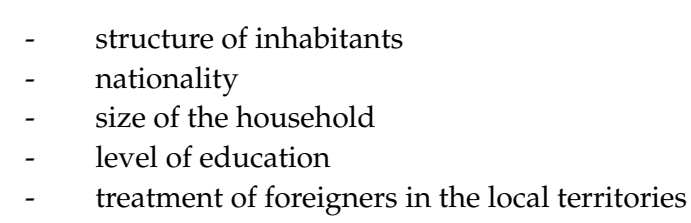

\section{Environmental}

- $\quad$ housing information

- $\quad$ quality and volume of resources delivered and produced in the local territory

- $\quad$ environmental information (SE-protected areas, protection and sustainable usage of sea resources)

- $\quad$ property structure

- $\quad$ ecological structure (SE-sea resources and the influence of climate changes on these resources)

\section{Cultural}

- cultural activities.

- $\quad$ free time for local inhabitants (cafes, walks, forest, shops, short migration, homes, and sport)

- $\quad$ number of tourists per year, spent financial resources

- $\quad$ historical links with the territory, traditions in the local community (coffee, sauna, fish smoking, berry picking, etc.) (SE-fishing traditions, recreation traditions)

- $\quad$ population activity and level of cooperation with the municipality (in the village, village elder, Facebook group, WhatsApp group, etc.)

\section{Service basket}

- $\quad$ taxi

- $\quad$ public transport

- $\quad$ regional and government centres

- $\quad$ regulations in place

- $\quad$ health services

- $\quad$ shop services

One of groups "specific sea resources (in the water and inland)" is defined as a horizontal factor group that is part of the sub-factors and shown in Table 1 marked with SA.

Economic factors impact the design of the economic development of the village or neighbourhood, and this requires information about the employment, wages, salaries, real estate in the local territory, migration, and entrepreneurship in the local territory (village or neighbourhood) and in the municipality (region). These economic factors will provide the main information regarding the planning of the territory development and analysis of the economic health in the local territory and community. By using this information, the community and local government can analyse the economic activities inside 
the local territory and the economical manner of the local inhabitants. Economic factors are known to be in synergy with social factors, including life quality and satisfaction in the family and in the society (community), and they reflect the environment of the local territory as well.

Social factors present the interrelatedness of the social roles, behaviours and actions of the local community, providing detailed information regarding the social structures in the local territory to analyse the age, nationality and education. This information identifies the analytical categories and relationships between them, i.e., the needs of the local community from the age and ethnographical view.

Environmental factors play important roles in the local territory through infrastructure development (public, municipal and private) by indicating the structure and housing information. The environmental factors are closely linked to the social factors. The factors of the environmental give important information regarding the minimum needs for stays in a village or neighbourhood including:

- the drinking water and sewers;

- the roads and their quality;

- the energy saving possibilities; and

- the ecological situation.

Cultural factors include the traditions, attitudes, beliefs, values and self-definitions of the local community, which are important in territory planning and can show information regarding the free time and leisure activities in the territory and nearby territories. To collect this information, there are no optimal parameters regarding how far from the village or neighbourhood the free time activities should be located, but this parameter must be an attribute.

Government service basket factors include information on what services can be obtained directly from the government in the developing territory and how far it is to obtain services for health, shopping and local and regional centres. These factors also include restrictions on territory development and protection zones.

Specific sea resources (in the water and inland) must be analysed to collect and monitor information that is based on the smart specialization of coastal areas. It is important to analyse the resources that are directly connected to the sea in the water and those inland. This will not be a separate indicator (not included in the Table 1); however, certain indicators must be specifically analysed regarding the differences of coastal local territories (marked with SA in the lower table).

There is an issue regarding the interdisciplinary harmonized indicator classifications [30]. Every stakeholder attempts to use their own indicators, although there are many developed Ecosystem Services (ES) indicator models. In future research, we will attempt to harmonize the local level indicators with ES indicators.

\subsection{Methods for Collecting the Values for Indicators and Its Data Sources}

For analysing local territories, methods that produce accurate and precise data should be chosen. These data must cover the largest part of the territory and most of the inhabitants. Triangulation involves the use of different methods and sources to check the integrity of, or extend, the inferences drawn from the data. Triangulation has been widely adopted and developed as a concept by qualitative researchers as a means of investigating the 'convergence' of both data and the conclusions derived from them [31]. This technique is often cited as one of the central methods of 'validating' qualitative research evidence.

The methods for collecting of the data:

- mapping of the geospatial data—geodetical surveying on the field, use the geospatial databases to collect the environmental data;

- $\quad$ survey-use mutual and written methods, use social forms, also possibly use the GIS platform;

- interview-collect the cultural information and needs for inhibitors; 
- observations-collect information on the habits and behaviours; and

- analyse documents-collect information on the services and regulations of the government, the decisions of the government and submissions.

Data sources for the information vary from maps to databases (see Figure 6):

- geospatial databases (textual and graphical);

- $\quad$ statistical databases;

- archives; and

- on the field collection.

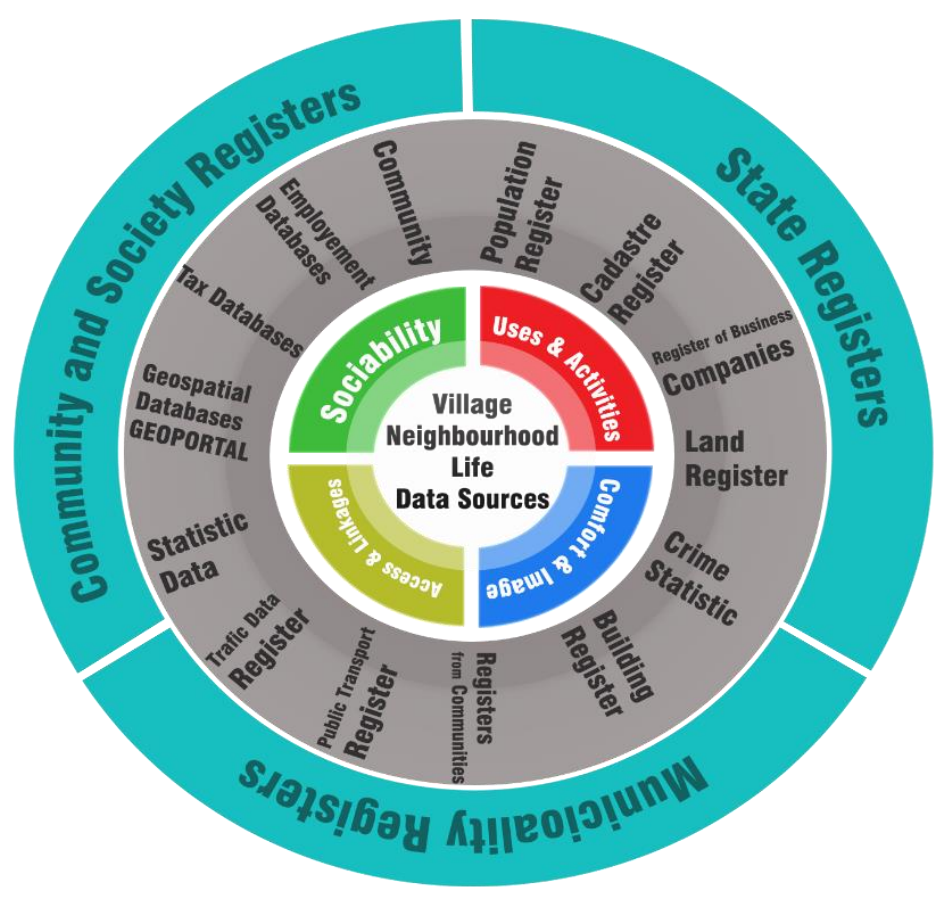

Figure 6. Data sources for indicators (developed by the authors).

In this respect, in the village or neighbourhood planning, the indicators mainly focus on the local needs and people's lives by using the hard data and integrating it in the GIS tools. In village planning, a GIS is the tool to collect, analyse and visualize the results. Spatial analysis results from the GIS give the tasks for the future to show what the village needs and what is possible to do. Combining the different geospatial and analytical layers is possible (see Figure 6). For example, for analysis of the population, to show the needs and analyse the possibilities in the village or surrounding area is possible. The GIS tool can help organize the life in villages.

\subsection{Methods for Analyzing and Visualizing Indicators}

There is a possibility to use many of the methods to analyse the village or neighbourhood life indicators. There are two primary important categories: statistical and/or logical methods. For visualizing, it is possible to use combinations of the analytical data and cartographical maps, or to use the GIS and statistical and/or logical methods for describing, illustrating, reducing, summarizing and evaluating the data $[32,33]$. Based on the data, these methods allow us to draw inductive conclusions and separate the signal (the phenomenon of interest) from the noise (statistical fluctuations or subjective bias) in the data. A GIS gives a connection with the place and possibilities to visualize the results with the geographical features to provide interactions with different data layers.

Considering the discussion part of this present research, we designed the information system architecture of the indicator analysing tool (Figure 7). 


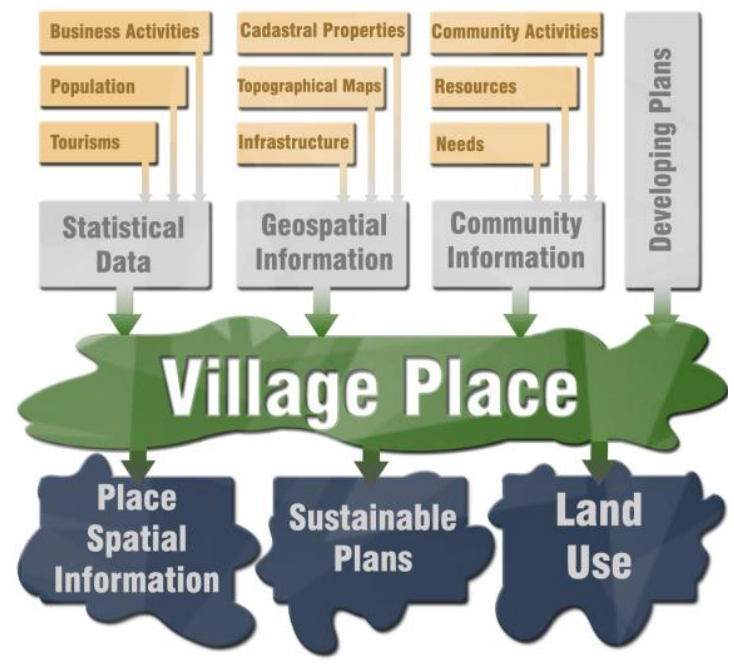

Figure 7. The information system architecture of the indicator analysing tool (developed by the authors).

According to Figure 7, the results of the indicator analysis tool must show the main possibilities for communications, needs and possibilities to develop the village or neighbourhood territory. The tool will allow for understanding and analysis of the economic, environmental, social, service and cultural factors, as well as specific sea resources (in the water and inland), including the scenarios and forecast approach. The results can also indicate threats to sociality and economical possibilities, as well as possibilities for using the strengths of the local community. In future research regarding the village or neighbourhood indicator analysis tool, more detailed characteristics of indicators and GIS layers will be developed. The results must be dynamical and open to changes in adapting to circumstances.

\section{Conclusions}

The territory-developed methods for the evaluation of economic and social processes, as well as the methods of analysis for territory development data are widely studied in the scientific literature. The obtained results (indicators) are used in forecasting, planning and in defining strategic directions of development at various territorial levels. Territory planning is usually used in larger planning units-municipalities, regions or states. The planning of smart and sustainable villages and neighbourhoods in Baltic Sea coastal areas can be considered a sufficiently new concept, which needs to be further detailed with new approaches and examples.

We explored local territory planning for the villages and neighbourhoods in Baltic Sea coastal areas in the context of using a GIS, and we highlighted its topicality for the development of local needs-based planning approaches. To approach the objective, we developed three indicator groups (statistical data, geospatial information and dynamic information) that influence village or neighbourhood planning. We demonstrated the primary idea of using the hard data and a GIS by designing the information system architecture of the indicator analysis tool.

Indicators are a tool used to help to analyse the present and predict the future development of villages and neighbourhoods in Baltic Sea coastal areas based on credible evidence. A GIS is one of the best ways to present and process statistical and geospatial information using spatial analysis methods, e.g., geoprocessing. The indicators provide a potential contribution to the social, economic and sustainable development of a local territory and the growth in quality improvement (potential future layers). This creates better communities for future generations and establishes viable communities, local planning services and urban and regional planning. In the development of brownfields and the land development plans can be adjusted to reach most of the expected results from inhabitants through stakeholder dialog and cooperation (to develop a cohesive community). 
The effective application of indicators is possible in cooperation with village representatives and municipal specialists, ensuring the flow of information to the GIS database. A GIS can function fully when ensuring a regular flow of information. Regular discussion between the community and the municipality is a method to identify new indicators. The existing biodiversity, ecosystem, climate changes and specific sea resources (in the water and inland) are crucial factors that will affect the future local community life of the coastal areas. It is important to highlight these and the balance among nature, humans and economic growth. The local needs-based planning approach for smart and sustainable development in the villages and neighbourhoods can provide a more inclusive society in the coastal areas supported using a GIS.

Author Contributions: Conceptualization, M.K., S.G. and E.P.; methodology, M.K.; software, M.K.; validation, A.L., E.P. and S.G.; formal analysis, J.H. and U.K.; investigation, M.K.; resources, M.K.; data curation, M.K.; writing-original draft preparation, M.K.; writing-review and editing, S.G. and E.P.; visualization, M.K. and A.L.; supervision, S.G. and E.P.; project administration, S.G. All authors have read and agreed to the published version of the manuscript.

Funding: This research was funded by the INTERREG Central Baltic program project "Coast4us" within the P2 project priority-Sustainable use of the common resources, project number 627.

Conflicts of Interest: The authors declare no conflicts of interest.

\section{References}

1. Holms, J.; Arhipova, I.; Vitols, G. Linking environmental data models to ecosystem services' indicators for strategic decision making. In Proceedings of the ICEIS 2018-20th International Conference on Enterprise Information Systems, Funchal, Portugal, 21-24 March 2018; Volume 1.

2. Project for Public Spaces (2016). Available online: https://www.pps.org/ (accessed on 20 November 2019).

3. Gollana, N.; Voyer, M.; Jordan, A.; Barclay, K. Maximising Community Wellbeing: Assessing the Threats to the Benefits Communities Derive from the Marine Estate. Ocean. Coast. Manag. 2019, 168, 12-21. [CrossRef]

4. Reveiu, A.; Dârdală, M. Techniques for Statistical Data Visualization in GIS. Inform. Econ. 2011, 15, 72.

5. Cimdina, A.; Raubiško, I. Cilvēks un Darbs Latvijas Laukos. Sociālantropoloógisks Skatījums; Zinātne: Rīga, Latvia, 2012.

6. Kalibatas, D. The Multi-Attribute Assessment of Environmental Factors Influencing on Dwelling-houses. In Summary of Doctoral Dissertation; Vilnius Gediminas Technical University: Vilnius, Lithuania, 2009; 22p.

7. Kārklina, R. Lauku Kopienu, Pašvaldību un Valsts Iestāžu Sadarbība Attīstības Plānošanā. No, A. Cimdina, \& I. Raubiško (Sast.). In Dzīve, Attīstība, Labbūtība Latvijas Laukos; Zinātne: Rīga, Latvia, 2012; pp. 67-87.

8. Clout, D.H. The Countryside: Towards a Theme Park. In the Oxford Handbook of Postwar European History; Stone, D., Ed.; Oxford University Press: Oxford, UK, 2012. [CrossRef]

9. Bently, G.; Pugalis, L. Shifting Paradigms: People-centred Models, Active Regional Development, Space-blind Policies and Place-based Approaches. Local Econ. 2014, 29, 283-294. [CrossRef]

10. Ernsteins, R.; Kaulins, J.; Zilniece, I.; Lontone, A. Coastal Governance Solutions Development in Latvia: Collaboration Communication and Indicator Systems. Coastal Zones; Elsevier: Amsterdam, The Netherlands, 2015.

11. Franceschini, F.; Galetto, M.; Maisano, D. Management by Measurement: Designing Key Indicators and Performance Measurement Systems; Springer Berlin Heidelberg: Torino, Italy, 2007; 242p. [CrossRef]

12. Gallopin, G.C. Indicators and their use: Information for decision-making. In Sustainability Indicators; Moldan, B., Billharz, S., Eds.; Wiley: New York, NY, USA, 1997; pp. 13-28.

13. Bossel, H. Assessing viability and sustainability: A systems-based approach for deriving comprehensive indicator sets. Conserv. Ecol. 2001, 5, 12. [CrossRef]

14. Future Trends in the Baltic Sea. 2010. Available online: http://assets.wwflv.panda.org/downloads/wwf_ future_trends_in_the_baltic_sea_2010_1.pdf (accessed on 23 October 2019).

15. Meyerson, M.; Banfield, E.C. Politics, Planning, and the Public Interest; Free Press: New York, NY, USA, 1955.

16. Holms, J.; Arhipova, I.; Tulbure, I.; Vitols, G. Ecosystem Provisioning Services Automated Valuation Process Model for Sustainable Land Management. Procedia Comput. Sci. 2017, 104, 65-72. [CrossRef]

17. ESPON. EDORA European Development Opportunities for Rural Areas; ESPON: Luxembourg, Germany, 2013; 81p. 
18. Casini, M.; Bastianoni, S.; Gagliardi, F.; Gigliotti, M.; Riccaboni, A.; Betti, G. A Methodological Proposal for a Multidimensional Fuzzy Index in the Mediterranean Area Sustainable Development Goals Indicators. 2008. Sustainability 2019, 11, 1198. [CrossRef]

19. Momtaz, S.; Zobaidul Kabir, S.M. Evaluating Community Participation in Environmental Impact Assessment. In Evaluating Environmental and Social Impact Assessment in Developing Countries, 2nd ed.; Elsevier: Amsterdam, The Netherlands, 2018; Chapter 6; pp. 123-140. [CrossRef]

20. O’Brien, M.; Tsiropoulos, Y.; Smets, E.; Forsell, N.; Valin, H.; Lindner, M.; Moiseyev, A.; Verburg, P.; Verhagen, W.; Bringezu, S. Tools for Evaluating and Monitoring the EU Bioeconomy: Indicators. Deliverable 2.2 of the SAT-BBE Project; European Commission: Brussels, Belgium, 2014.

21. MacQueen, K.M.; McLellan, E.; Metzger, D.S.; Kegeles, S.; Strauss, R.P.; Scotti, R.; Blanchard, L.; Trotter, R.T. What is Community? An Evidence-based Definition for Participatory Public Health. Am. J. Public Health 2001, 91, 1929-1938. [CrossRef] [PubMed]

22. Ju, C.Y.; Jia, Y.G.; Shan, H.X.; Tang, C.W.; Ma, W.J. GIS-Based Coastal Area Suitability Assessment of Geo-Environmental Factors in Laoshan District, Qingdao. 2012. Available online: https://www.researchgate.net/publication/258685714_GISbased_coastal_area_suitability_assessment_ of_geo-environmental_factors_in_Laoshan_district_Qingdao (accessed on 20 October 2019).

23. Malczewski, J. GIS-Based Land-Use Suitability Analysis: A Critical Overview. Available online: http: //staff.unila.ac.id/ekoefendi/files/2011/10/Malczewski_2004.pdf (accessed on 20 October 2019).

24. Tomlin, C.D. Geographical Information Systems and Cartographic Modeling; Prentice-Hall: Englewood Cliffs, NJ, USA, 1990.

25. Hopkins, T.S.; Bailly, D.; Stottrup, J.G. A Systems Approach Framework for Coastal Zones. Ecol. Soc. 2011, 16, 25. [CrossRef]

26. Denzin, K.N.; Lincoln, S.Y. Handbook of Qualitative Research; Sage Publications, Inc.: Thousand Oaks, CA, USA, 1994; 643p.

27. Parker, D.C.; Manson, S.M.; Janssen, M.A.; Hoffmann, M.J.; Deadman, P. Multiagent systems for the simulation of land-use and land-cover change: A review. Ann. Assoc. Am. Geogr. 2003, 93, 314-337. [CrossRef]

28. Project for Public Spaces. 2016. Available online: https://uploadsssl.webflow.com/5810e16fbe876cec6bcbd86e/ 5a626855e27c0000017efc24_Healthy-Places-PPS.pdf (accessed on 23 October 2019).

29. Kārklina, R. Vai Laukos ir Pilsoniskā Sabiedrība? No, B. Bela, E B. Zepa (Zin.red.). Identitātes. Kopienas. Diskursi; LU Akadēmiskais apgāds: Rīga, Latvia, 2012; pp. 47-60.

30. Cano, E.L.; Moguerza, J.M.; Ermolieva, T.; Yermoliev, Y. A strategic decision support system framework for energy-efficient technology investments. TOP 2017, 25, 249-270. [CrossRef]

31. Galdeano-Gómez, E.; Aznar-Sánchez, J.A.; Pérez-Mesa, J.C. The Complexity of Theories on Rural Development in Europe: An Analysis of the Paradigmatic Case of Almera (South-east Spain). Sociologia Ruralis. 2011, 51, 54-78. [CrossRef]

32. Pudzis, E.; Geipele, S.; Geipele, I. Community Participation in Village Development: The Scale of Latvia. Balt. J. Real Estate Econ. Constr. Manag. 2016, 4, 84-99. [CrossRef]

33. Auziňš, A.; Geipele, S. Creative Destruction for Sustaining a Land Development in Residential Areas; Riga Technical University: Rīga, Latvia, 2016; pp. 283-294.

(C) 2020 by the authors. Licensee MDPI, Basel, Switzerland. This article is an open access article distributed under the terms and conditions of the Creative Commons Attribution (CC BY) license (http://creativecommons.org/licenses/by/4.0/). 